\title{
GAUCHOS, MONTONERAS Y CAUDILLOS: UNA INTERPRETACIÓN A TRAVÉS DE LA HISTORIETA EL CHUMBIAO, DE FERMÍN CHÁVEZ Y JUAN ARANCIO
}

\author{
Gauchos, Montoneras and Leaders: an Interpretation through the Comic Strip \\ El Chumbiao by Fermín Chávez and Juan Arancio
}

Mónica Alabart*

\section{Resumen}

El Chumbiao es una historieta cuyo guión fue escrito por el historiador Fermín Chávez con dibujos de Juan Arancio, que apareció en Clarín en enero de 1967 y narra las aventuras de Gerónimo Romero, un gaucho matrero jordanista. Este artículo analiza cómo en el marco de un registro no académico como el de la tira El Chumbiao que ficcionaliza un momento de la historia argentina del siglo XIX, paradójicamente los autores construyen una representación de la participación de los sectores populares, los gauchos, que integraban las montoneras federales, superadora de las miradas clásicas del propio revisionismo y se emparenta con perspectivas actuales que los consideran actores políticos.

$<$ Gauchos $><$ montoneras $><$ revisionismo $><$ rebelión jordanista $>$

\begin{abstract}
El Chumbiao is a comic strip whose screenplay was written by the historian Fermín Chávez with drawings of Juan Arancio. This comic strip appeared in Clarín on January 1967, and it narrated the adventures of Geronimo Romero, a gaucho matrero jordanista. Hence, El Chumbiao fictionalizes one point in the history of the nineteenth century in Argentina. This article analyzes how, under a non-academic record as the comic strip El Chumbiao, the authors paradoxically construct a representation of the participation of the popular sectors, the gauchos, who formed the federal montoneras, that overcomes the classic views of the revisionism itself, and is related to current perspectives that consider them as political actors.
\end{abstract}

$<$ Gauchos $><$ montoneras $><$ revisionism $><$ jordanista rebellion $>$

Recibido: 29/03/2015 // Aceptado: 08/10/2015

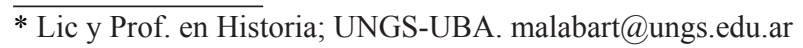




\section{Introducción}

"A fines de 1870, fuerzas de López Jordán comandadas por un gaucho a quien le decían "El Chumbiao" cercaron la ciudad de Paraná. Una noche aprovechando un descuido de la guarnición, los montoneros lograron atravesar las defensas y dieron, a caballo, toda la vuelta de la plaza central, golpeándose la boca y burlándose. Luego, entre pifias y silbidos, se fueron. La guerra no era para ellos la ejecución coherente de un plan sino un juego de hombría". (Borges, 2011: 428)

Contaba Jorge Luis Borges que esta anécdota pertenecía a la tradición oral de su casa. ${ }^{1}$ En su relato, el escritor recuperaba el hecho histórico introduciendo una manera de ver lo que representaba la guerra para los gauchos, para las montoneras que integraban los ejércitos federales, así en su mirada: "la guerra no era para ellos la ejecución coherente de un plan sino un juego de hombría". Las masas de jinetes nómades no encaraban la guerra con un propósito sino como un juego de masculinidad, coraje, ostentación, no sabían obrar de otro modo, no sabían qué hacer frente a la ciudad. ${ }^{2}$

Sobre este suceso singular se conservan documentos históricos y el historiador Fermín Chávez pudo reconstruir otra versión de cómo habían sido los hechos. Sin embargo, nos interesaba comenzar con esa imagen literaria, ya que además de referirse específicamente al tal "Chumbiao" y a la trascendencia de sus "hazañas" que llegaron a través de la tradición oral, expresa una representación sobre el gaucho y las montoneras del siglo XIX que coincide con la tradición interpretativa que la historiografía conformó a partir de la mirada de las elites decimonónicas liberales. En esa interpretación, "montonera" designaba una forma inorgánica de acción armada de los sectores populares rurales que brindaban su apoyo a algún caudillo, un jefe local o regional que se caracterizaba por un ejercicio "bárbaro" de la autoridad. Los montoneros mantenían lazos de obediencia y lealtad con sus caudillos, y el fervor y el entusiasmo con que luchaban eran considerados producto de atavismos sociales, de la adhesión ciega al líder o como resultado de la manipulación de éste sobre la base de relaciones paternalistas (Fradkin, 2006).

Gauchos, montoneras y caudillos fueron resignificados por la historiografía revisionista en su desafío por construir una visión de la historia que impugnara la interpretación heredada de la tradición liberal. En su perspectiva resultó clave la ruptura con la identificación entre barbarie y caudillismo y la reivindicación de los caudillos del interior y las luchas de las montoneras federales de la segunda mitad de siglo XIX como exponentes de un proyecto nacional popular frustrado. Sin embargo, en su mirada no

${ }^{1} \mathrm{Su}$ abuelo, el coronel Francisco Borges participó en la represión de la rebelión jordanista y estuvo en la defensa de la ciudad de Paraná ocupada por las fuerzas nacionales en 1870. En el texto "Historias de Jinetes" el gaucho "El Chumbiao" fue recuperado por el escritor junto a una lista de otros gauchos literarios más famosos como Fierro, Cruz, el gaucho de El Payador y Don Segundo Sombra (Borges, 2011: 428-429).

2 Sandra Contreras realiza un interesante análisis de este poco conocido texto de Borges (Contreras, 2008). 
innovaron con respecto al estudio de la participación popular y sus trabajos se centraron en los caudillos, en los líderes.

Fermín Chávez fue uno de los historiadores de la corriente que se abocó al estudio de los caudillos -entre ellos el entrerriano Ricardo López Jordán-y las montoneras federales de ese período; publicó diversos trabajos en las décadas de 1960 y 1970. En esos años, convocado por el diario Clarín junto al dibujante Juan Arancio, crearon la historieta El Chumbiao basada en la figura del capitán Gerónimo Romero, aquél gaucho integrante de las fuerzas de López Jordán del que escribía Borges, contando sus aventuras a partir de la derrota de la primera rebelión jordanista en Ñaembé.

Como ha sido señalado, gauchos y montoneras fueron fundamentales en el proceso histórico argentino del siglo XIX y en la formación de la cultura nacional, sin embargo, su tratamiento en la historiografía ha sido desparejo y a pesar de los renovados enfoques sobre el tema, discernir las motivaciones, las ideas, las intenciones de los grupos populares al momento de pasar a la acción sigue siendo uno de los problemas más complejos de la historia popular. De acuerdo con Di Meglio y Fradkin (2013) en algunos casos, los ensayos o los relatos de ficción reponen las voces y la agencia de los sectores populares proponiendo conjeturas que la historiografía no puede resolver.

En este artículo analizamos cómo en otro ámbito de expresión por fuera del marco académico, como el de la historieta El Chumbiao, que cuenta las aventuras de un gaucho matrero en el contexto de las rebeliones de López Jordán, paradójicamente, Chávez propone una interpretación de la participación de los sectores populares, los gauchos que integraban las montoneras federales, que complejiza las miradas clásicas del propio revisionismo y se emparenta en algunos aspectos con perspectivas actuales que buscan reponer la experiencia de la participación popular y su relación con los caudillos, sus motivaciones, estrategias y orientaciones ideológicas considerándolos como actores políticos.

\section{Montoneras y Caudillos en la interpretación revisionista}

Para los primeros revisionistas las cuestiones de las montoneras y los caudillos no fueron preocupaciones centrales ya que su interés sobre el pasado estaba más vinculado a la elaboración de una interpretación en torno a las consecuencias ocasionadas por el vínculo establecido entre Argentina y Gran Bretaña y en la condena al colonialismo. ${ }^{3}$ No obstante, desde su mirada crítica a la perspectiva liberal, en contra de esa historia que llamaron "falsificada", Julio y Rodolfo Irazusta, Manuel Gálvez, Ramón Doll, Ernesto Palacio, Ricardo Font Ezcurra, entre otros, agrupados en el Instituto de Investigaciones

\footnotetext{
3 Halperín Donghi menciona que la primera obra representativa del revisionismo La Argentina y el imperialismo británico, de Julio y Rodolfo Irazusta, publicada en 1934, era parte de una severa condena a la firma del pacto Roca-Runciman que había constituido a la Argentina en un dominio británico y buscaba las raíces de esa abominación en el pasado nacional, para encontrarla en la presencia de una oligarquía, que exceptuando el período de Rosas, dominó la vida del país durante un siglo. El eje pasaba por la condena al imperialismo y no consagraba a la figura de Rosas, ni a su régimen ningún examen detenido (Halperín Donghi, 2005: 23-24). También se refiere al mismo tema (Buchbinder,1998: 46).
} 
Alabart. Gauchos, Montoneras y Caudillos: una Interpretación a través de la historieta el chumbiao, de Fermín...

Históricas "Juan Manuel Rosas", fundado en 1938, comenzaron a ocuparse directa o indirectamente del problema del caudillismo.

A pesar de la heterogeneidad y diversidad que caracterizó a los autores de la corriente, sus interpretaciones compartían la reivindicación de Juan Manuel de Rosas como defensor de la soberanía y forjador de la unidad nacional. ${ }^{4}$ Dos aspectos de la gestión de su gobierno resultaron particularmente atractivos: uno, era la capacidad del gobernador caudillo de crear un fuerte liderazgo por encima de las clases y grupos de la sociedad que gobernaba, logrando mediatizar no sólo a las clases populares sino también a las elites; el otro, estaba vinculado al enfrentamiento de las amenazas externas, especialmente la resistencia a los dos bloqueos, coronados por el triunfo, en uno de los cuales había participado Gran Bretaña (Halperín Donghi, 2005: 22).

También coincidían en que los caudillos del interior habían tenido un papel relevante en las primeras décadas de vida independiente en la defensa de los valores católicos, de un orden paternalista y de los intereses provinciales frente al centralismo porteño y liberal. Sin embargo, los caudillos del interior tuvieron una presencia muy escasa en las primeras publicaciones del instituto. Las referencias a ellos eran generales y sólo hubo algunos artículos y conferencias que se ocuparon de su tratamiento. ${ }^{5}$

Las interpretaciones sobre el caudillismo de los primeros autores revisionistas se centraron fundamentalmente en: discutir y negar la identificación entre barbarie y caudillismo, propia de las obras clásicas de la historiografía liberal, atribuir la responsabilidad de las guerras civiles a los gobiernos centrales, afirmar que los caudillos habían encarnado la reacción popular contra el centralismo abusivo y señalar la vinculación entre caudillismo y federalismo. ${ }^{6}$

Si bien el rosismo y la época de Rosas siguieron ocupando un lugar importante en las publicaciones del instituto, durante las décadas de 1950 y 1960 algunos historiadores revisionistas se dedicaron a reivindicar a los caudillos de la segunda mitad del siglo XIX tales como Ángel “Chacho" Peñaloza, Felipe Varela y Ricardo López Jordán, entre otros. Los libros de Fermín Chávez, Vida y Muerte de López Jordán (1957), Vida del Chacho. Ángel Vicente Peñaloza (1967) y de Rodolfo Ortega Peña y Eduardo Luis Duhalde Felipe Varela contra el imperio británico (1966), fueron una clara expresión del interés que motivaba la problemática. Tanto fue así, que hacia mediados de la década de 1960 al interior de la propia corriente se produjo un debate en torno al caudillismo que

\footnotetext{
${ }^{4}$ Obras como Juan Manuel de Rosas. Su vida, su drama, su tiempo (1930) de Carlos Ibarguren; Ensayo sobre Rosas (1936), de Julio Irazusta; Vida de Don Juan Manuel de Rosas (1940), de Manuel Gálvez; son parte de esta producción historiográfica. Si bien cabe mencionar que había muchas diferencias entre las miradas que los propios revisionistas brindaban sobre Rosas, lo que llevó a Ramón Doll en un artículo publicado en la revista del propio instituto a hablar de un "rosismo de derecha" y un "rosismo de izquierda", estas diferencias estaban vinculadas con la utilización política de sus planteos (Cataruzza, 2003: 153-155).

5 Hay muy pocos trabajos sobre los caudillos de la primera mitad del siglo XIX aunque el instituto realizaba homenajes que recordaban anualmente a Manuel Dorrego y a Facundo Quiroga.

6 Particularmente la obra global de este primer revisionismo de Ernesto Palacio, La historia falsificada (1939) y los textos de Ricardo Font Ezcurra (1940) y de Julio Irazusta (1946).
} 
tuvo como principales protagonistas a los anteriores autores mencionados. ${ }^{7}$ La polémica se desencadenó a partir de las afirmaciones expresadas por Ortega Peña y Duhalde en su libro sobre Felipe Varela, a las que Fermín Chávez consideró "apreciaciones erróneas" de los autores sobre la actitud de la escuela revisionista con respecto al caudillo catamarqueño y los montoneros (Chávez, 1966). La principal cuestión estaba vinculada a que Ortega Peña y Duhalde habían señalado que el "excesivo rosismo" del revisionismo dificultó el acercamiento de los historiadores de la corriente a la figura de Felipe Varela, lo que sumado a la participación del caudillo en la Coalición del Norte contra Rosas, su proclama de 1866 y su adhesión a Urquiza, lo habían hecho aparecer a los ojos de revisionistas como una especie de "anti-Rosas", un personaje de menor jerarquía. Chávez consideraba que esas críticas eran simplificadoras y carecían de base documental. Varela y Peñaloza habían sido tratados por diversos autores en las décadas de 1940 y 1950 y escritores revisionistas habían visto a Varela y el Chacho no como anti rosistas sino como caudillos populares representantes del sentimiento federal de las provincias después de Pavón. ${ }^{8}$

Chávez demostraba que la recuperación de los caudillos del interior de la segunda mitad del siglo XIX por autores enrolados en el instituto era anterior a la obra de Ortega Peña y Duhalde, lo que claramente parecía diferenciar los trabajos entonces, era que esa reivindicación en los primeros estaba más ligada al carácter de líderes de masas populares, en tanto que en los segundos, se hallaba vinculada al rol clave que asumieron en la lucha contra el imperialismo. Ortega Peña y Duhalde consideraban el antiimperialismo de Felipe Varela como una continuación de un plan político que había tenido a Rosas como su principal ejecutor al mismo tiempo que consideraban a las montoneras como expresión de la lucha de las clases del campesinado proletario contra la oligarquía terrateniente, y veían en ellas un movimiento político de carácter igualitarista (Ortega Peña y Duhalde, 1966: 10, 130-131, 163-164).

Para Chávez los caudillos de la segunda mitad del siglo XIX como Varela, el Chacho y López Jordán encarnaban la "defensa del interior, de la Argentina Continental frente a la Argentina del Puerto. Una defensa no demasiado clara, nítida, con sus más y sus menos" (Chávez, 1975). En Vida del Chacho, plantea que luego de la subordinación comercial de Urquiza a los hombres del puerto después de la batalla de Pavón y su

\footnotetext{
En la década de 1960, las diferencias políticas internas entre los miembros del instituto y las dificultades económicas provocaron la interrupción de la publicación de la revista y la separación de algunos de sus integrantes. De todos modos, los conflictos internos continuaron, en parte motivados por la continuidad y la renovación de sus colaboradores, sobre todo por la incorporación de ex miembros del Movimiento Nacionalista Revolucionario Tacuara; así, viejos nacionalistas, peronistas y promotores de un nuevo revisionismo volcado hacia el peronismo de izquierda protagonizaron la polémica. En ese contexto, se desató el debate historiográfico en torno al caudillismo, al que hacemos referencia. El otro tema que generó polémica fue la Guerra del Paraguay (Stortini, 2004).

8 Fermín Chávez cita a numerosos autores que se habían dedicado a la investigación sobre el Chacho Peñaloza: desde las páginas de Corvalán Mendilaharzu, Ricardo Caballero y Dardo López de la Vega, hasta autores revisionistas como Santos López. Menciona que en 1949, Dardo de la Vega Díaz y Héctor Barrionuevo, revisionistas no rosistas, dieron a conocer un valioso material sobre Felipe Varela y la batalla de Pozo de Bargas. Por último, cita también sus propios trabajos de la década del ' 50 en los que se había ocupado de Felipe Varela (Chávez, 1966: 11).
} 
defección de la causa federal, fueron los jefes populares como el Chacho y López Jordán quienes siguieron defendiéndola (Chávez, 1967).

Más allá de los diferentes momentos e interpretaciones al interior de la corriente, nos interesa destacar que si bien el revisionismo recuperaba a los caudillos acentuando su rol de líderes y representantes de las clases populares, o como defensores de los intereses nacionales frente al imperialismo, sus trabajos se centraron en ellos, limitándose a celebrar el apoyo popular y la participación del pueblo en las montoneras sin generar estudios historiográficos sobre las clases que estos líderes representaban.

Por consiguiente, resulta interesante analizar la mirada de Fermín Chávez sobre la participación popular a partir de la historieta El Chumbiao, basada en un personaje subalterno como el capitán Gerónimo Romero, ya que desde un registro no académico, desde una reconstrucción ficcional, en la que como decía el autor "no pesan los límites de la historiografía" propone una interpretación de la acción de los gauchos y las montoneras que no abordó en sus estudios históricos.

\section{Cuando la historia visita a la leyenda: Gerónimo Romero "El Chumbiao"}

"Cuando la historia visita a la leyenda", así titulaba el diario Clarín un artículo escrito por Fermín Chávez en su revista del domingo 15 de enero de 1967, en el que anunciaba a sus lectores que había comenzado a publicar la historieta "El Chumbiao". Informaba que tras una intensa y erudita búsqueda, se había logrado reconstruir la vida del capitán Gerónimo Romero, un matrero que peleó a las órdenes de Ricardo López Jordán en Entre Ríos y fue compañero de José Hernández: "Ahora la vida épica del personaje asoma en la historieta de Clarín" (Clarín Revista, 15 de enero, 1967: 4).

Chávez contaba que junto al historiador Aníbal S. Vázquez habían comenzado la búsqueda del personaje histórico sin ninguna impaciencia, con algunos datos precisos de sus hazañas y prontamente ayudados por su apodo, encontraron noticias en la prensa periódica de la época. En una nota de junio de 1870, un corresponsal de guerra de $L a$ Capital de Rosario que circunstancialmente se encontraba en Costa del Quebracho, una localidad ubicada a doce leguas de Paraná, le escribía al redactor del diario en pleno contexto de la rebelión jordanista mencionando al tal Chumbiao como "capitán" de una gavilla de salteadores que andaban cometiendo delitos escondidos en los montes. (Chávez, 1967a: 4).

Las crónicas de la prensa citada por Chávez se emparentan con la imagen que transmitían los documentos de las autoridades políticas. El capitán Gerónimo Romero oriundo de Gualeguay, perteneció a la facción federal y en 1865 participó en los desbandes de tropas de Basualdo y Toledo que se opusieron a marchar a la Guerra del Paraguay,$^{10}$ debió hacerse matrero por ese entonces. En una carta que le enviaba Manuel

\footnotetext{
9 Esta afirmación de Chávez explicitando que se trataba de un registro diferente en cual no regían las reglas del discurso historiográfico proviene de la nota que cometamos más adelante, en la que Clarín, presentaba la historieta a sus lectores (Chávez, 1967a: 4).

${ }^{10}$ En nuestra investigación sobre las deserciones de Basualdo y Toledo, nos encontramos con documentación que imputaba a Gerónimo Romero como un promotor de los desbandes. Cartas del jefe político de Nogoyá Coronel Manuel Navarro a Urquiza lo acusaban de incentivar a los hombres a no concurrir al
} 
Navarro, jefe político de Nogoyá, al general Urquiza, le informaba que le remitía a Rafael Rodríguez "muchacho vagabundo y haragán" que era hermano de "aquel sargento Romero conocido como el Chumbiao, que andaba haciendo barullos cuando yo reunía mi división en la Cañada Grande". ${ }^{11}$ Lo habían perseguido sin poder tomarlo y en ese momento, noviembre de 1866, sabía que se encontraba mandando una partida de salteadores en el Departamento de Paraná.

Posteriormente, Romero se integró a las tropas de López Jordán actuando a lo largo de la primera campaña. En mayo de 1870 con el comienzo de la rebelión estuvo a cargo de la toma de la ciudad de Paraná. Allí ocurrió el hecho singular que referimos en el epígrafe de Borges a través de la versión oral. El suceso quedó documentado por Patricio Texo, el ex cónsul de Brasil en Paraná, en una carta que le escribió al ministro de Guerra y Marina general Juan Andrés Gelly y Obes:

"Mi querido amigo: Hoy de cinco a seis de la mañana hemos pasado un mal rato, más por la vergüenza que por el peligro. 300 a 400 gauchos se han entrado hasta la plaza principal donde había como 400 infantes durmiendo al estremo que los Sentinelas los sintieron cuando se los llevaban por delante pero a los primeros tiros hulleron. Esto ha sido debido a la completa nulidad de las autoridades militares, pues la tropa ni las armas tenía cargadas, en fin es una vergüenza...". ${ }^{12}$

La situación fue que después de dar unas vueltas a la plaza, gritando vivas a la patria y a su jefe, los jordanistas se retiraron sin encontrar resistencia; el propio Romero, le escribía a López Jordán desde Tres Sauces:

"En cumplimiento de la orden recibida de S:E, me marché para el pueblo de Paraná con 200 hombres y a las cinco y media de la mañana estuve en la plaza principal dando vivas en la puerta de la jefatura de la policía a nombre de la patria y de V:E... Luego les hicieron fuego a las demás partidas que había esparcido en distintos puntos y no pareciéndome propia la pelea dentro del pueblo para no ofender a la población, ordené la retirada a los oficiales que encabezaban dichas comisiones a las orillas del pueblo donde yo me retiré, parando a ver si salían los traidores enemigos para combatirles". ${ }^{13}$

reclutamiento diciendo que Ricardo López Jordán no iba a marchar a la guerra. Manuel Navarro a Justo J. de Urquiza, Nogoyá, Campamento de las puntas de Cañada Grande, 23-9-1865, Fondo Urquiza, Archivo General de la Nación (Alabart, 2015).

${ }^{11}$ Navarro M. a Urquiza, J.J, Nogoyá, 12 de noviembre de 1866, FU, AGN.

${ }^{12}$ Carta de Patricio Texo al ministro de Guerra y Marina Juan A. Gelly y Obes, 30 de mayo de 1870, Paraná, Archivo personal de Fermín Chávez (Chávez, 1967a: 4).

${ }^{13}$ Carta de Gerónimo Romero a Ricardo López Jordán, 20 de mayo, Tres Sauces, Archivo López Jordán, en poder de Fermín Chávez (Chávez, 1967a: 5). 
De acuerdo con este testimonio, el episodio no había ocurrido a fines de 1870 como relataba Borges sino el 20 de mayo y los jordanistas encabezados por el Chumbiao se retiraron, no porque la "guerra no fuera para ellos la ejecución coherente de un plan", sino porque después de despertar a los gritos a la infantería enemiga dormida, Romero ordenó a sus fuerzas concentrarse a las afueras del pueblo para evitar la pelea dentro del mismo y esperar allí para combatir. Su parte de guerra proseguía:

“...y después de algunas horas de haber estado allí esperando si salían, tuve aviso que el Señor Coronel Ibarra había salido para afuera antes con 100 y tantos hombres y que se hallaba en la Costa del Sauce y temiendo ser abatido por nuestra retaguardia por algún aviso que tuviese.

Me puse en marcha sobre él y habiendo llegado al punto le encontré en marcha con al pueblo y después de haber tendido la línea de fuerza para combatirle, me mandó propuesta que no quería pelear en contra de sus paisanos y compañeros de armas, a lo que nos estrechamos a conferenciar, dándome la mano y un fuerte abrazo, como igualmente la tropa...". ${ }^{14}$

Finalmente, Ibarra se puso a disposición de López Jordán comprometiéndose con sus fuerzas a atacar a los enemigos que estuvieran en Paraná cuando éste lo considerara oportuno. Los jordanistas no habían sufrido bajas y Romero terminaba su parte a la espera de nuevas órdenes.

Hicimos una larga referencia a este episodio porque son escasos los testimonios de los propios actores subalternos y nos daba la posibilidad de reponer las palabras de Romero en una acción por la cual pertenece a la memoria colectiva. ${ }^{15}$ El hecho que describe formó parte de una serie de acciones que se desencadenaron a partir del desembarco de las fuerzas nacionales a la provincia que dio comienzo a las Rebeliones Jordanistas. ${ }^{16}$ De acuerdo con su testimonio, el ataque a la ciudad de Paraná correspondía

\footnotetext{
${ }^{14}$ Carta de Gerónimo Romero a Ricardo López Jordán, 20 de mayo, Tres Sauces, Archivo López Jordán, en poder de Fermín Chávez (Chávez, 1967a: 5).

${ }^{15}$ Un problema de la historia popular es que siempre aparece como acción colectiva, lo que torna muy difícil reconstruir biografías populares ya que carecemos de documentos, sólo contamos con fragmentos, referencias aisladas, expedientes judiciales, registros de terceros. Por ese motivo nos pareció muy valioso transcribir un documento del propio protagonista que refiera al hecho. Sobre el tema de la dificultad para encontrar las voces de los propios actores subalternos, ver la interesante entrevista a Ricardo Piglia en (Di Meglio y Fradkin, 2013: 429-459).

${ }^{16}$ El 11 de abril de 1870 Justo J. Urquiza fue asesinado por una partida de federales encabezada por Simón Luengo; a los pocos días la Legislatura provincial eligió a Ricardo López Jordán como gobernador provisorio y el presidente Domingo F. Sarmiento sancionó un decreto nombrando al general Emilio Mitre comandante en jefe del ejército de observación que debía vigilar las costas del río Uruguay y por el cual lo autorizaba a requerir a los gobiernos de Corrientes y Entre Ríos las milicias que creyera necesarias. El 19 de abril comenzó el desembarcó de las fuerzas nacionales en Gualeguaychú. López Jordán intentó a través de la Legislatura provincial exigir el retiro de las fuerzas nacionales del territorio de la provincia y
} 
a una operación organizada siguiendo órdenes impartidas por López Jordán, y la decisión de no pelear dentro de la ciudad respondió a la incapacidad de respuesta de la infantería y a la estrategia del propio Romero de "evitar ofender" a los pobladores, probablemente en una búsqueda de legitimar sus acciones y conseguir adhesiones para la "causa".

Este suceso tuvo su trascendencia y la fama de Romero fue creciendo. En septiembre de 1870, el periódico jordanista La Nueva Era ofrecía a sus lectores una fotografía del capitán Romero y un anuncio expresaba: “¡Retratos! Se hacen en la fotografía francesa-inglesa. De todos los tamaños y los gustos. En la misma casa se vende el retrato del comandante Romero y muchos otros". ${ }^{17}$ Fermín Chávez encontró la fotografía; la misma estuvo en manos de Jorge Luis Borges quien la había recibido del coronel Francisco Borges. ${ }^{18}$

Figura 1. Retrato de Gerónimo Romero Fotografía ofrecida por el periódico jordanista La Nueva Era en 1870

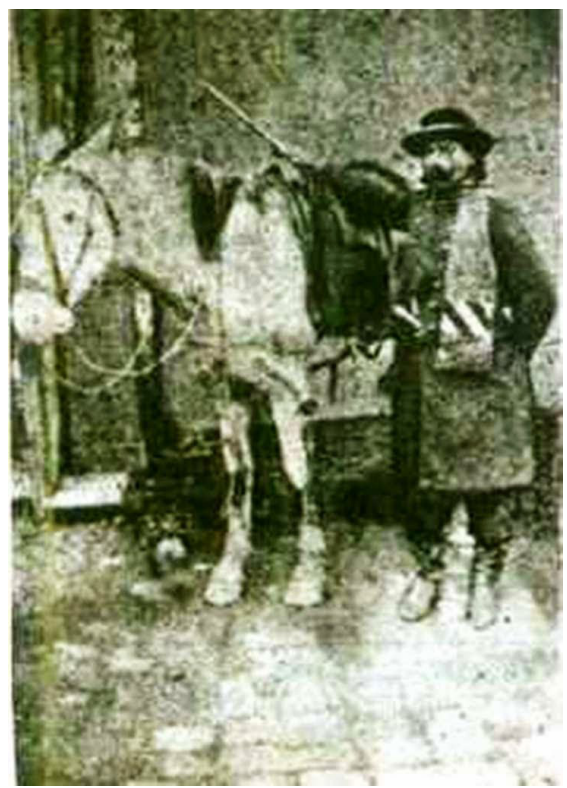

Fuente: Clarín Revista, domingo 15 de enero, 1967.

Todavía en esos años, los retratos fotográficos representaban un signo de status de las elites, ${ }^{19}$ por este motivo es sumamente interesante que se conserve una fotografía

ante la negativa, el 23 de abril lanzó su proclama, la guerra había sido traída por los "eternos enemigos", "nuestra guerra no es sino en sostén de la autonomía de Entre Ríos" (Chávez, 1957: 204-22).

${ }^{17}$ La Nueva Era, Gualeguay, septiembre, 1870 (Chávez, 1967a: 5).

${ }^{18}$ Chávez contó que la fotografía estaba en poder de Amaro Villanueva, que antes había estado en manos de Carlos Mastronardi y de Jorge Luis Borges por legado de su abuelo, la misma tenía al pie un autógrafo del coronel Francisco Borges. El diario publicó la fotografía en una nota que escribió Fermín Chávez dando a conocer a los lectores el comienzo de la publicación de la historieta "El Chumbiao" (Chávez, 1967a: 5).

${ }^{19}$ En los primeros años del daguerrotipo el negocio de la fotografía fue monopolizado por los 
Alabart. Gauchos, Montoneras y Caudillos: una Interpretación a través de la historieta el chumbiao, de Fermín...

de Gerónimo Romero. El retrato del Chumbiao parece una imagen cuidadosamente construida. ${ }^{20}$ Que el estudio fotográfico vendiera la foto y el aviso se publicara en un diario jordanista de Gualeguay muestra un propósito reivindicatorio de su figura en un contexto de guerra en el cual los periódicos cumplían un rol importante como transmisores de noticias y propaganda para la causa. ${ }^{21}$ De esta manera, al hacerse eco de sus hazañas, el periódico contribuía a su popularidad, desafiando a la prensa opositora liberal y a las autoridades que lo denostaban como un bandido.

Según las escasas referencias documentales, Romero siguió participando en diversas acciones hasta la batalla de Ñaembé. Por una crónica periodística de la época, sabemos que después de esa derrota, como muchos otros jordanistas, partió al exilio y allí terminó sus días. El periódico La Libertad de Olegario V. de Andrade publicaba en septiembre de 1871: "El Chumbiao, personaje de la rebelión ha muerto en la emigración de una parálisis contraída en las pasadas campañas"22.

La historieta "El Chumbiao" toma comobase el personaje histórico, la geografía entrerriana, el espacio temporal en qué vivió pero es el Chumbiao, transfigurado en sus rasgos físicos, imaginado en el exilio, "como en el Martín Fierro de Hernández..." decía Fermín Chávez. ${ }^{23}$

retratistas, hasta 1860 y aún en los siguientes el elevado precio que debía pagarse, hizo que la fotografía fuera un lujo para las clases acomodadas. De acuerdo con Andrea Cuarterolo, las fotografías, como otros documentos son un producto de la sociedad que las crea. Jacques Le Goff propone hablar de documentos como monumentos. En ese sentido deben verse los retratos, como una construcción a través de los cuales las elites decimonónicas buscaron imponer una determinada imagen sobre sí mismas. Nos interesa pensar en la aplicación de ese análisis para el retrato fotográfico de un "héroe" popular como Romero (Cuarterolo, 2006).

${ }^{20}$ La fotografía del Chumbiao está tomada en el exterior aunque no impacta un paisaje rural ya que se pueden ver los adoquines. Como en esa época la inmovilidad y los largos tiempos de exposición eran una necesidad técnica, habitualmente la pose era acordada con el fotógrafo. En la escena sobresalen Romero y su caballo, éste además de un bien muy preciado, tenía una importancia simbólica para los entrerrianos que eran famosos por sus fuerzas de caballería.

${ }^{21}$ En los meses de julio, agosto y septiembre de 1870, los jordanistas tenían el control gran parte de Entre Ríos, estaban bajo su poder los departamentos de Villaguay, Federación, Diamante, Nogoyá, Gualeguay y Victoria. Contaban con cuatro periódicos que cumplían con las funciones de propaganda y de difundir noticias: El independiente, que redactaba Antonio Descalzo de Uruguay, El Avisador de Gualeguaychú, El Obrero Nacional de Nogoyá, redactado por el padre José M. Zattoni y luego Francisco Fernández, y La Nueva Era redactado por Segundo Gianello, de Gualeguay, la ciudad del Chumbiao (Chávez, 1957:236).

${ }^{22}$ La libertad, Concordia, septiembre, 1871 citado en Chávez (1967a:5).

${ }^{23}$ Señalamos que entre los gauchos El Chumbiao y el Martín Fierro encontramos más diferencias que similitudes, análisis que excede la propuesta de este trabajo. La frase de referencia en: Chávez (1967a:5). 
Figura 2. "El Chumbiao" Dibujo de Juan Arancio

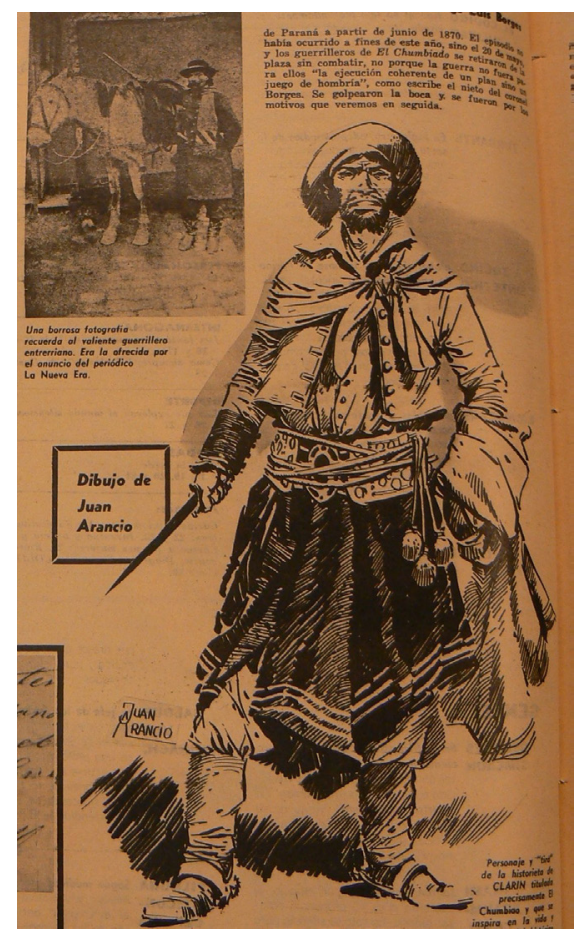

Fuente: Clarín Revista, domingo 15 de enero, 1967.

Si bien el guión está pensado desde ese punto de partida ficcional, el infortunio de un hombre destinado a huir, la historieta es un medio a través del cual los autores cuentan su interpretación de la resistencia de la última montonera federal en los primeros años de 1870. La trama se desarrolla entre la derrota de Ñaembé en 1871 y termina antes del segundo levantamiento jordanista en 1873. El 26 de enero de 1871 las fuerzas nacionales conducidas por el entonces joven teniente coronel Julio A. Roca derrotaron a los 7000 hombres que integraban la montonera federal dirigida por el caudillo entrerriano. A partir de ese momento, el general Ricardo López Jordán se refugió en Santa Ana do Livramento en Brasil; varios dirigentes federales tuvieron que exiliarse en Brasil, Uruguay o en otras provincias argentinas como Santa Fe; los restos de sus fuerzas se desbandaron y algunos de sus hombres cayeron presos. La provincia de Entre Ríos, intervenida por el gobierno nacional desde el asesinato de Urquiza, continuó militarizada, con autoridades provinciales impuestas y una población descontenta. En ese contexto histórico se mueve el héroe de la historieta.

\section{Gauchos, montoneras y caudillos en la Historieta "El Chumbiao"}

Cuando el diario Clarín comenzó a publicar “El Chumbiao”, las tiras gauchescas ya llevaban varias décadas en la prensa nacional. ${ }^{24}$ Como mencionamos anteriormente,

\footnotetext{
${ }^{24}$ Ya en 1929 el diario Crítica de Natalio Botana editaba las primeras tiras de corte gauchesco, como las de
} 
Alabart. Gauchos, Montoneras y Caudillos: una Interpretación a través de la historieta el chumbiao, de Fermín...

el diario convocó a Fermín Chávez como guionista y a Juan Arancio como dibujante para realizar la tira. En ese momento, Chávez tenía una trayectoria como historiador identificado con la corriente revisionista nacionalista y había trabajado como redactor en el diario desde $1960 .{ }^{25}$ Arancio era conocido en el medio por sus trabajos para las editoriales Hora Cero, Frontera y Columba, a la vez que por su dominio de temas de tipo histórico y gauchesco. ${ }^{26}$

"El Chumbiao" se publicó diariamente desde enero de 1967 hasta agosto de 1969 en la contratapa del diario. ${ }^{27}$ Era la única historieta nacional en una página cubierta por tiras importadas. ${ }^{28}$ Ante el boom del género en los años anteriores y el éxito que en ese momento tenían algunas tiras gauchescas que se editaban en otros diarios, resulta comprensible que Clarín decidiera comenzar a publicar una tira con esta temática. ${ }^{29}$

Raúl Roux Ramauge El tigre de los llanos y Martín Fierro, en 1939 La Razón publicaba Cirilo, el audaz, con guión y dibujos de Enrique Rapela , en 1951 comenzó a publicar Cabo Savino, de Carlos Casalla y Julio Álvarez Cao y en 1954 Lindor Covas, el Cimarrón de Walter Ciocca , en 1957 en La Prensa aparecía El Huinca y en 1964 Fabián Leyes ambas de Enrique Rapela, por mencionar algunas. Cabe señalar que la Segunda Guerra Mundial provocó una crisis en la importación de las tiras lo que alentó la producción nacional y fue durante la década de 1950 cuando el género gauchesco hizo su eclosión (Levin, 2015:75-76).

${ }^{25}$ Militante peronista, trabajó en la Secretaría de Salud Pública de la Nación y luego en la Dirección General de Cultura bajo la dirección de Castiñeira de Dios durante el gobierno de Perón y en los años de la Resistencia Peronista integró el Comando Táctico creado por el líder del movimiento. Junto a Héctor Tristán y otros compañeros de "Línea dura" editó "De Frente", un boletín que transmitía las directivas de Perón desde el exilio, y exhortaba a los peronistas a votar en blanco en las elecciones constituyentes de 1957. Para la década del sesenta ya había publicado Civilización y Barbarie (1956) Vida y muerte de López Jordán (1957) José Hernández, periodista, político y poeta, (1959) Alberdi y el Mitrismo (1961) entre otros.

${ }^{26}$ Nacido en Santa Fe, autodidacta, sus primeras creaciones fueron los personajes "Terry Dick" (luego convertido en Santos Bravo) y "El Gaucho Saverio". A nivel nacional comenzó a trabajar en los años 1950 colaborando como dibujante en la editorial Hora Cero. En 1960 tomó a su cargo la serie "Patria Vieja" que aparecía en Hora Cero Extra y otras de similar temática que se publicaron en Frontera Extra, como "Invasiones", un conjunto de cinco episodios recreando las Invasiones Inglesas. En esta misma etapa en Editorial Frontera publicó su personaje "Santos Bravo" con guiones de Oesterheld, En 1961 ilustró una adaptación del "Martín Fierro". Casi simultáneamente con sus trabajos para Frontera colaboró con Editorial Columba donde su dominio del tema lo hizo imprescindible en todas aquellas adaptaciones de tipo histórico y gauchesco. Al margen de esos numerosos trabajos Arancio volvió a publicar con guiones propios "Santos Bravo" (Fantasía, 1966) y realizó en D'Artagnan: Pehuén Curá", creada por Julio Álvarez Cao. Años después con sus propios guiones Arancio publicó El Chumbiao en la revista El Tony. http://allerastur.lacoctelera.net/post/2008/12/01/gauchos-genero-gauchesco-ya-quiencuente.

${ }^{27}$ Salió por primera vez el lunes 2 de enero de 1967 y se terminó de editar el día sábado 30 de agosto de 1969. No se publicaba los domingos y nunca se realizó una reedición completa. Fue difícil su búsqueda ya que en la hemeroteca de la Biblioteca Nacional falta la última página de los ejemplares de Clarín de esos años, y en la del Congreso los diarios están microfilmados y se pierde la riqueza de ver directamente las viñetas en papel. Agradezco a Agustín Maurín, director del archivo de Clarin y al personal del archivo por la amabilidad y la asistencia que me brindaron para relevar la tira.

${ }^{28}$ El Chumbiao compartía la contratapa de Clarín, con Mutt y Jeff de Fisher; Vida de Hogar de Swan, Daniel, el travieso, de Hank Ketcham y Los Picapiedras de Hanna Barbera todas tiras norteamericanas.

${ }^{29}$ En ese momento el vespertino La Razón ya llevaba trece años editando Lindor Covas, el Cimarrón de Walter Ciocca con un éxito tan notable entre sus lectores que lo habían convertido en "una marca 
Si bien en la historieta gauchesca se han destacado los ilustradores y se suelen citar en primer término como autores, ${ }^{30}$ en este caso, la presencia de Fermín Chávez le dio relevancia a su rol de guionista. Esto explica por qué el diario decidió anunciar a sus lectores que había comenzado a publicar "El Chumbiao" con el extenso artículo que comentamos en el apartado anterior, en el cual el historiador se ocupaba de contar quién era el personaje histórico que había servido de inspiración para crear al héroe de la tira.

En el mismo artículo, Chávez se encargaba de explicitar que en la tira el personaje había sido tomado en una época posterior a la que había vivido en la que no "pesaban" los límites de la historiografía. Ahora bien, se ha señalado que la historieta gauchesca se apoya en un fuerte documentalismo que otorga verosimilitud a los hechos y las situaciones, en la distancia temporal y en un cierto grado de estereotipia de las situaciones, aspectos que al mismo tiempo que favorecen la narración de la aventura, limitan sus posibilidades expresivas (Sasturain, 1995: 58-59). Sin embargo, frente a las exigencias metodológicas del trabajo académico, los límites que imponían esas reglas no explícitas pero vigentes en la tradición de las tiras gauchescas, habilitaron para el historiador, un ámbito de expresión y de divulgación diferente, donde lo "imaginario posible" abrió un camino fructífero para la evocación del pasado.

Fue así que partiendo de un conocimiento exhaustivo del período y mediante una cuidadosa documentación histórica y gráfica, Chávez y Arancio mezclaron la ficción y la historia para narrar los caminos del matrero jordanista Gerónimo Romero.

El dibujo de Arancio está basado en ilustraciones y grabados realizados por una prestigiosa tradición de pintores viajeros e ilustradores de obras gauchescas del siglo $\mathrm{XIX},{ }^{31}$ a los cuales les imprimió su profunda observación de la geografía del litoral. A diferencia de otras tiras gauchescas que tienen como escenario el inconmensurable "desierto" pampeano, ${ }^{32}$ los protagonistas de "El Chumbiao" se desplazan por los paisajes del litoral con sus ríos, árboles de espinillos, aguaribay, palmares, montes, islas y bañados que fueron hábitat y refugio de supervivencia para los paisanos perseguidos

identificatoria del diario", según Sasturain (1995:243) y ya habían por su contratapa Hormiga Negra y el primer Cabo Savino.

${ }^{30}$ Refiriéndose a la historieta gauchesca por ejemplo Juan Sasturain afirma que: "Rapela, Roume, Casalla y sus correspondientes guionistas están más cerca de Hernández y del comandante Prado en su veracidad reconstructiva..." (1995: 60). También menciona a la historieta "Nahuel Barros" como de RoumeOesterheld.

${ }^{31}$ Desde los pintores viajeros del siglo XIX como el francés Raymond Quinsac Monvoisin, el bávaro Johann Moritz Rugendas, el brasileño de origen francés Juan León Pallière y los argentinos Carlos Morel, Prilidiano Pueyrredón y Carlos Clérici, el ilustrador de La Vuelta de Martín Fierro (1889), una larga tradición fue retomada por los dibujantes de historietas gauchescas como Juan Arancio, Enrique Rapela y Walter Ciocca. Representaciones del gaucho en el arte rioplatense del siglo XIX en Malosetti Costa: 2001.

32 Desde Cirilo, el audaz (1939) ambientada en la época de Rosas, El Huinca (1957) y Fabián Leyes (1964) de Enrique Rapela, pasando por Lindor Covas, el Cimarrón de Walter Ciocca o Cabo Savino, (1951) de Carlos Casalla y Julio Álvarez Cao, las más populares historietas gauchescas desarrollaban su acción en el "desierto" pampeano. Una visión de la pampa fuertemente ideologizada que se reproduce en las historietas como ese ámbito hostil, habitado por salvajes que se extiende más allá de la frontera. Sobre esa construcción en las imágenes (Malosetti Costa y Penhos, 1991). 
Alabart. Gauchos, Montoneras y Caudillos: una Interpretación a través de la historieta el chumbiao, de Fermín...

por las autoridades. ${ }^{33}$ Hay una lograda recreación del paisaje, los ranchos, la vestimenta, los uniformes, las armas, las carretas, los caballos, como así también, de las costumbres y muchos rasgos del vocabulario presentes en la literatura gauchesca de Hernández. ${ }^{34}$

Figura 3. Montecito de Talas y Ñandubay refugio de matreros del litoral. Chávez y Arancio

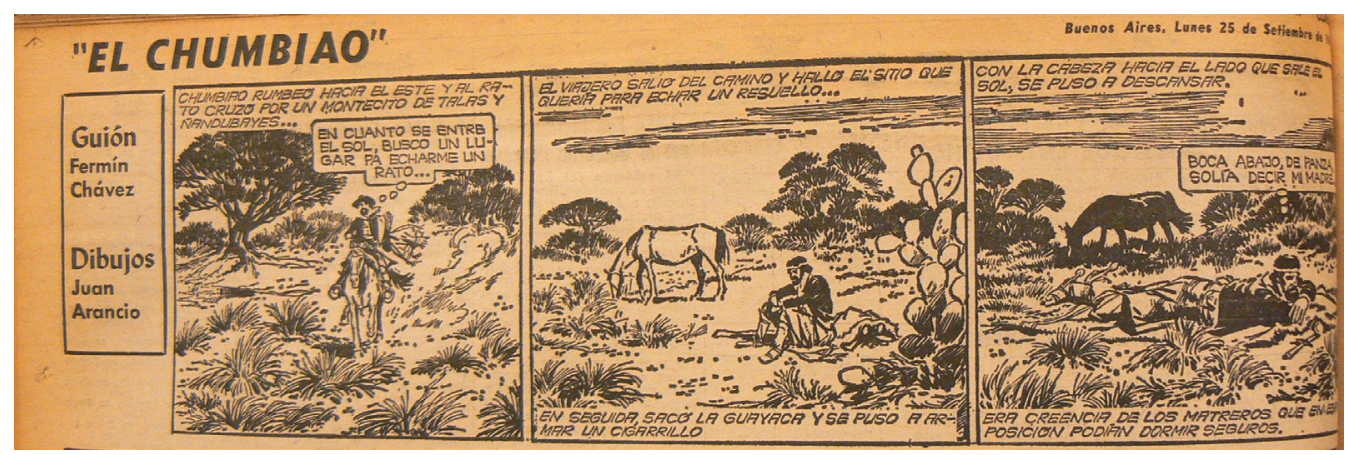

Fuente: "El Chumbiao", Clarín, lunes 25 de septiembre de 1967.

El relato comienza en la Mesopotamia a principios de 1871 cuando Gerónimo Romero, el Chumbiao, “un gaucho derrotado en batalla y en desbande”, es perseguido por una partida de nacionales que quieren remitirlo a Paraná por ser integrante del ejército jordanista. Logra escapar y tras varios contratiempos llega a su rancho donde descubre que está abandonado y que su mujer Marciala se ha perdido. Se lleva a su ahijado y decide huir hacia San Javier; sabe que el partido ha quedado desmembrado, pero que el general López Jordán va a volver. ${ }^{35}$ Muchos de sus compañeros han partido al exilio, otros sufren la persecución y los grillos. Pero por fuera y por dentro de la provincia de Entre Ríos se está conspirando contra el gobierno impuesto por Sarmiento. Los autores reconstruyen ese clima a través de la trama: así, el Chumbiao se contacta con importantes jefes federales; es un agente que lleva cartas secretas, organiza una montonera, arma un plan para liberar a sus compañeros presos políticos; va atravesando

\footnotetext{
${ }^{33}$ Hacia fines del siglo XIX, José Sixto Álvarez, más conocido por su seudónimo Fray Mocho, señalaba que la población más heterogénea..."vive perdida entre los pajonales que festonean las costas entrerrianas"; allí en las tierras bajas de los bañados y las islas: "se halla en el país de lo imprevisto, de lo extraño; en la región que los matreros han hecho suya por la fuerza de su brazo y la dejadez de quienes debieranimpedirlo; en la zona de la república donde las leyes del Congreso no imperan, donde la palabra autoridad es un mito, como lo es el presidente de la república o el gobernador de la provincia" (Álvarez, José, 2003) Tierra de Matreros, Biblioteca Virtual Universal. http://www.biblioteca.org.ar/libros/10059.pdf

${ }^{34}$ De acuerdo con Jorge B. Rivera es posible emparentar la historieta gauchesca con una larga tradición que proviene del folletín, especialmente del ciclo gauchesco de José Hernández y Eduardo Gutiérrez. Los dibujantes argentinos de historietas se sintieron atraídos por los gauchos y la colección de episodios legendarios que poblaban sus historias, las tareas rurales de la estancia, la Conquista del "Desierto" sin descontar las obras literarias como el Martín Fierro, de José Hernández o las novelas de Eduardo Gutiérrez que fueron fuente de inspiración y tuvieron una potente influencia. "El Chumbiao" con sus particularidades claramente pertenece al "género". Sobre la historieta gauchesca, ver Rivera Jorge, 1992. Panorama de la historieta en la Argentina, Buenos Aires, Libros del Quirquincho.

${ }^{35}$ Chávez y Arancio, "El Chumbiao", Clarín: 7-3-1967.
} 
diversas ciudades y encontrando apoyo de la población cansada de las persecuciones, confiscaciones de campos y las contribuciones del gobierno de Echagüe.

¿Quiénes son los gauchos representados en la historieta? Desde las primeras viñetas, el Chumbiao se define como: "un montonero en derrota", ${ }^{36}$ un gaucho, capitán del ejército jordanista, que se volvió matrero y está huyendo por una causa política. Enseguida, se topa con otros gauchos en la pulpería que comentan: "El gauchaje tá en desgracia","Nos toca vivir juyendo", "Dicen que nos mandarán a la infantería...", "Nos patean como a yeguarases". ${ }^{37}$ Los gauchos riojanos cuentan que la pobreza los ha mandado a rodar; uno, era minero y terminó arriero, el otro, "tenía una tropa e'carretas pero aura con el ferrocarril me hei quedao pa dar lástima". ${ }^{38}$

Estos son algunos de los gauchos que se hacen matreros como el Chumbiao con los que se va encontrando a lo largo de su camino. Por lo que podemos ver, las procedencias son diversas; algunos, eran desertores del ejército que no querían ser llevados a la infantería, otros, eran trabajadores rurales que vivían de la agricultura, la cría de ganado, la minería o arrieros, que huían de la "miseria" y otros, eran perseguidos políticos, desterrados como el Chumbiao. Todos tenían en común que andaban huyendo rebelados contra la autoridad.

Según Chávez, para entender el período que se extiende desde Caseros hasta la aparición del Martín Fierro de Hernández (1872) había que detenerse en el estudio del gaucho matrero, que no es una calificación jurídica, de derecho penal, sino una categoría política; es la contrapartida de los criollos sin tierra a la arbitrariedad de las ordenanzas y las leyes contenidas en la fórmula "vagos y malentretenidos". Los gauchos matreros son rebeldes políticos que se multiplican después de Pavón (Chávez, 1969). En un sentido geográfico, habitaban la campaña, socialmente eran pobres, y las luchas de la década de 1860 los habían transformado en rebeldes políticos.

Los gauchos rebeldes federales fueron llamados por las autoridades de la época montoneros. El término se empleaba desde el comienzo de las guerras civiles para referirse a quiénes se rebelaban contra las autoridades, ya fueran departamentales, provinciales o nacionales. En algunos casos se hablaba de montonero o revolucionario como sinónimos (De la Fuente, 1998: 273). Ese uso del vocablo es el que se desprende de la caracterización de los personajes de la historieta. Para Chávez, montoneros son los gauchos rebeldes federales y los protagonistas se definen a sí mismos como tales, reivindicando el término, en clara confrontación con las autoridades.

En uno de los episodios de la tira, el Chumbiao se une a un grupo de gauchos riojanos en la campaña santafesina, entre los que también se encuentran un catamarqueño, un chileno, y milicianos desertores para dirigirse a la estancia de Prudencio Arnold, un veterano jefe federal, porque allí se encuentra Juan Saá, "Lanza Seca", que quiere contactar a López Jordán para coordinar un levantamiento. En el camino paran en la pulpería y allí se enteran de que hay rumores de que pronto Jordán va a invadir por la

\footnotetext{
${ }^{36}$ Chávez y Arancio, "El Chumbiao", Clarín, 13-1-1967.

${ }^{37}$ Chávez y Arancio, "El Chumbiao", Clarín, 9-2-1967.

${ }^{38}$ Chávez y Arancio, "El Chumbiao", Clarin, 7-7-1967.
} 
Alabart. Gauchos, Montoneras y Caudillos: una Interpretación a través de la historieta el chumbiao, de Fermín...

Banda Oriental y que está por pasar un tren que lleva armas para "los nacionales" que temen un alzamiento de Simón Luengo en Córdoba. Los montoneros deciden asaltar el tren, atrapan unas vacas cimarronas y las atraviesan sobre las vías lo que posibilita que se detenga y así logran quedarse con el cargamento de armas que llevan a la estancia. Allí, el Chumbiao se reúne con Saá y éste le entrega una carta para López Jordán que se encuentra exiliado en Santa Ana do Livramento. ${ }^{39}$

Tiempo después, luego de su encuentro con Jordán, Chumbiao intenta volver a Entre Ríos desde Uruguay con otra montonera, está vez formada por un pequeño grupo de gauchos blancos orientales del bando de Timoteo Aparicio y algunos desterrados entrerrianos. En la ciudad de Salto se entera de que están presos Francisco Fernández, Calandria y el padre Ordóñez, decide armar un plan para liberarlos. ${ }^{40}$ Acampan en las afueras de la ciudad y con la ayuda de una lavandera que era mujer de uno de los matreros consiguen unos uniformes de las fuerzas del gobierno para asaltar a la comandancia. Usan los uniformes, toman por sorpresa a los guardias y liberan a los prisioneros: "Fue grande la alegría de los tres presos políticos". ${ }^{41}$

Luego los montoneros se dirigen a Paysandú y desde allí, después de un Junta de guerra en la casa Robustiano Vera reunidos con otros jefes federales exiliados, Chumbiao y su montonera parten hacia Entre Ríos; el plan es "pasar con un grupo de gente armada y empezar a trabajar la provincia desde el centro... Fernández quedará en el Tala, el padre irá a Gualeguay y Vera a Nogoyá". ${ }^{42}$ Al día siguiente embarcan en unos lanchones rumbo a Entre Ríos pero al llegar a la costa los estaba esperando una partida de nacionales. Uno de los gauchos matreros había hablado de más en la pulpería. Después de una escaramuza, ante el empuje de los jordanistas, los nacionales, que no esperaban a tantos hombres bien armados, se retiran. Los montoneros curan a los heridos y se dirigen hacia el palmar para refugiarse y hacer campamento. Allí, Chumbiao ordena castigar duramente al gaucho culpable de lo ocurrido - el que había hablado de más en la pulpería- y carnean una vaca para celebrar el entrevero. ${ }^{43}$

Más allá de la situación ficcional que representan estos episodios, nos interesan como ejemplos de una manera de describir las lógicas de acción, el funcionamiento y las motivaciones de la montonera. En coincidencia con análisis de casos históricos, ${ }^{44}$ la acción de la montonera no aparece aquí como una reacción “espontánea” de parte de grupos rurales sin conciencia que carecen de objetivos políticos o son manipulados por

${ }^{39}$ Esta acción se desarrolla entre el lunes 17 de julio y el miércoles 16 de agosto de 1967, "El Chumbiao", Clarín, 17-7 a 16-8, 1967.

${ }^{40}$ Chávez va introduciendo personajes históricos que participan en la trama de ficción desde Ricardo López Jordán, José Hernández, Juan Saá, hasta Francisco Fernández, Ordóñez y el famoso matrero Servando Cardoso, más conocido como Calandria con quien comparte las acciones en este episodio.

${ }^{41}$ El episodio se desarrolla en "El Chumbiao", Clarín, desde el viernes 5 de enero al jueves 25 de enero, 1968.

42 "El Chumbiao", Clarin, 15-2-1968.

${ }^{43}$ El episodio se desarrolla entre el 22 de febrero y el 6 de marzo de 1967, "El Chumbiao", Clarín, 22-2 al 6-3-1967.

${ }^{44}$ La misma acción de Romero frente a la toma de la ciudad de Paraná que analizamos en el apartado anterior o las montoneras riojanas de la década de 1860 estudiadas por Ariel De la Fuente. (2007). 
sus caudillos como sostuvo durante largo tiempo la historiografía. ${ }^{45}$ Por el contrario, en las situaciones referidas, los gauchos representados en la tira definieron objetivos y los modos de alcanzarlos en forma autónoma o como parte de un plan elaborado por los jefes federales y algo que resulta interesante señalar, superaron los intereses inmediatos ya que esas operaciones estaban vinculadas con un objetivo de mayor alcance uniendo a los paisanos en la lucha por la misma causa.

Las acciones de las montoneras que se describen están ligadas a objetivos políticos; algunos más inmediatos como la toma de armas o la liberación de los presos políticos, y otras vinculadas a un plan de más largo alcance para preparar la provincia para la segunda rebelión jordanista. En ese aspecto hay una clara distinción entre esas acciones y las que cometen los bandidos o salteadores con los que se cruza el Chumbiao en algunas ocasiones. Las bandas de salteadores incurren en delitos -roban, matan, secuestran mujeres- sin otra finalidad que el pillaje. ${ }^{46}$

Con respecto al funcionamiento interior de la montonera, Chumbiao es el líder, toma las decisiones, da las órdenes, muestra una organización jerárquica que es respetada. En el episodio que narramos del castigo al gaucho que "habló de más" bebiendo en la pulpería, Chumbiao le consulta al padre Ordóñez su opinión cuando llegan al campamento y decide que lo retoben por traición. "En la guerra no se puede andar con blanduras, así que no le tengan lástima a ese cristo" dice Francisco Fernández. ${ }^{47}$ El Chumbiao, el cura Ordónez y Fernández son los jefes y deciden el castigo, acatado por los gauchos y que se justifica en la situación de guerra.

De esta manera, la estructura jerárquica, el cargo de capitán, la forma en que marcha la columna del Chumbiao, (figura 4) remiten a una organización miliciana en la caracterización de la montonera, a través de la cual los autores se aproximan a una imagen que concuerda con estudios recientes. Definir objetivos y los modos de alcanzarlos, decidir quién era el jefe de una movilización eran aspectos claves de la organización de una rebelión que estaba basada en una organización jerárquica que implicaba diferentes responsabilidades. La organización de las montoneras era similar a la de las milicias provinciales: "De allí que algunos gauchos interpretaran su participación en las mismas como una experiencia militar” (De la Fuente, 1998: 276).

\footnotetext{
${ }^{45}$ Especialmente en la historiografía producida en los países anglosajones con posterioridad a la década de 1960 el "caudillismo" fue tratado como una clase de clientelismo. Esa asociación fue central en la obra de John Lynch (1993). Un análisis del contraste entre la visión “clásica” del caudillismo y la visión clientelar del caudillismo en Goldman y Salvatore, 1998.

${ }^{46}$ Hay varios episodios en que el Chumbiao se encuentra con bandidos, en una ocasión los asaltan los hermanos Piri, unos bandoleros que junto a otros gauchos se dedican al pillaje y lo quieren degollar a él y al Chimango porque no tienen nada (El Chumbiao, Clarín, 7-3, 1969).

47 "El Chumbiao", Clarín, 4 de marzo de 1968.
} 
Figura 4. Montonera de Chumbiao. Chávez y Arancio

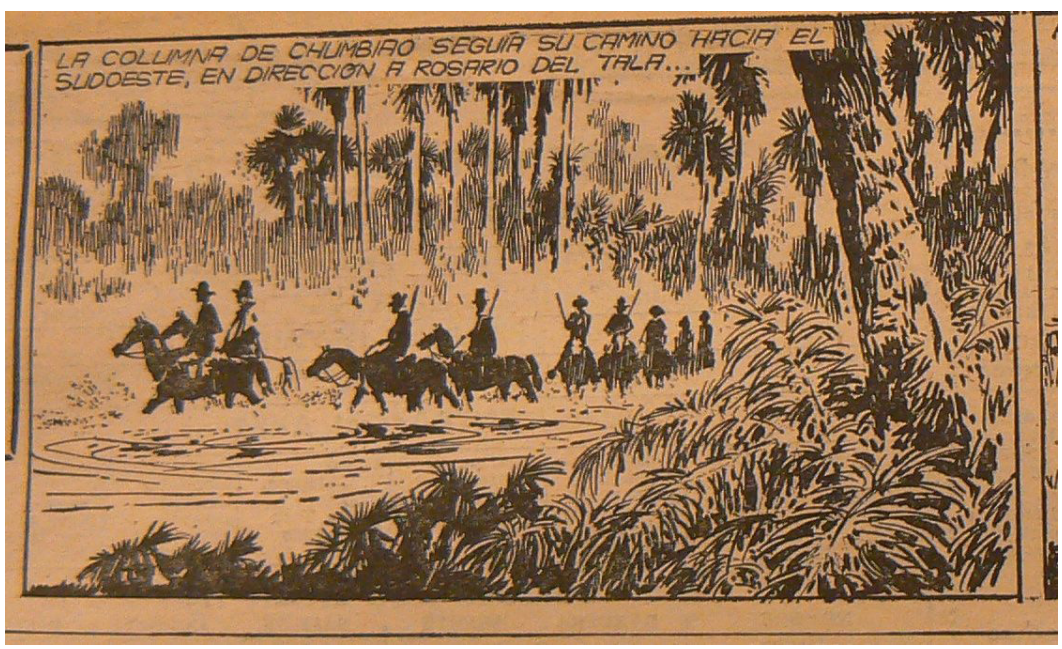

Fuente: "El Chumbiao", Clarín, lunes 18 de marzo de 1968.

Los montoneros de la columna del Chumbiao atraviesan Entre Ríos preparando la rebelión, carnean vacas cimarronas para sobrevivir (como en el episodio en el Palmar que narramos) pero también reciben el apoyo de pobladores locales. Camino a Nogoyá reciben comida y asistencia en una estancia; la curandera que atiende las heridas del Chimango tiene a su marido emigrado en el Uruguay con López Jordán, unos ancianos criollos lo alojan en su rancho y le cuentan que a sus caballos los requisó el gobierno. ${ }^{48}$ Hay un apoyo de la población a los montoneros jordanistas que está vinculado con la permanencia del ejército nacional en el territorio provincial, prolongada indefinidamente por Sarmiento, y con las duras condiciones que impone el gobierno de Echagüe tales como: la confiscación de campos y caballos que, para Chávez, constituían los más justos argumentos para fundar un nuevo levantamiento (Chávez, 1957: 252).

¿Qué razones llevaban a los gauchos a participar en la montonera? Como hemos señalado, después de la derrota de Ñaembé los principales líderes jordanistas partieron al exilio. En El revisonismo y las montoneras, Chávez menciona que antes del segundo levantamiento jordanista reapareció el general Juan Saá tratando de levantar las provincias de Cuyo para ayudar a la revolución entrerriana. Este fue el último intento de combinación entre las fuerzas federales. ${ }^{49} \mathrm{En}$ la historieta recrea ese intento de articulación entre el caudillo puntano y López Jordán. En el primer episodio que

\footnotetext{
${ }^{48}$ El episodio en el que llegan a la estancia de Don José López y el encuentro con la famosa curandera Doña Martiniana, se desarrolla en "El Chumbiao", Clarín, 14-6 al 21-6 -1968.

${ }^{49}$ Una carta de Juan Saá al Doctor Carlos María Querencio da cuenta de un acuerdo hecho entre ambos para que el primero dirigiera una revolución en las provincias del interior en apoyo a la de Entre Ríos. Pero mientras Querencio buscaba fondos para remitirle a Saá que necesitaba comprar armas, el ejército jordanista fue completamente derrotado en la batalla de Don Gonzalo y esa articulación nunca se produjo. Carta de Juan Saá a Carlos María Querencio, San Felipe, 16 de noviembre, 1873, Archivo del Dr. Carlos Ma. Querencio, publicada en Chávez: 1966: 60-62.
} 
narramos cuando Chumbiao se encuentra con los hombres de Saá podemos ver: por un lado, la decisión autónoma de los montoneros de asaltar el tren que lleva las armas para los nacionales, y por otro, la identificación de los gauchos con una lucha que va más allá de sus objetivos inmediatos y se vincula a una causa política: la defensa del federalismo. En la tira, los gauchos participan en las montoneras porque comparten la identidad política federal. La motivación central que los lleva a integrar las montoneras es la adhesión a la causa federal y al partido. "Si no fuera por el partido no me meto en esta milonga" dice Chumbiao cuando lleva las cartas de Saá para López Jordán. ${ }^{50}$ Los gauchos chilenos acompañan a Saá ${ }^{51}$ y los orientales a Chumbiao cuando vuelve a Entre Ríos desde Uruguay. Están unidos por una causa que trasciende la realidad provincial y se articula con otras luchas y otros líderes de proyección nacional e incluso más allá de las fronteras:
"Chumbiao: Uste no anda peliando al cuete... la divisa blanca es la mesma para los entrerrianos y orientales.
Secundino: Ansi es... pero yo soy mas que nada hombre de Timoteo Aparicio
Maragata: Todos peliamos por lo mismo Secundino, pa que los criollos no siamos carne de cogote". ${ }^{2}$

En este diálogo Chávez introduce tres dimensiones en la construcción de esa identidad que une a los gauchos que integran las montoneras: la divisa que está ligada al partido, que ya mencionamos, la relación con los caudillos, y la dimensión de clase.

La cuestión de los vínculos entre los caudillos y sus seguidores es central, ya que si bien Chávez no explicitó en sus trabajos las razones por las cuales las clases populares seguían a los caudillos federales en sus luchas, consideraba que éstos encarnaban sus intereses por eso el pueblo los respaldaba "con cuerpo y alma". ${ }^{33} \mathrm{En}$ la historieta, los gauchos se identifican como hombres de Saá, Jordán, Aparicio, en clara referencia a la vinculación con sus caudillos. Cuando éstos aparecen representados en la tira están

\footnotetext{
50 "El Chumbiao", Clarín, 25-8- 1967.

${ }^{51}$ En la referida carta a Carlos Querencio, Juan Saá le expresaba: "Para moverme de aquí lo are con una fuerza de trecientos hombres, entre argentinos y chilenos, digo trecien (sic) para abrirme paso al centro de las probincias qe. será el teatro de mis operaciones, y si pudiese contar con más recursos qe. los qe. Le pido me sería más fácil llevar mas jente”. Carta de Juan Saá a Carlos María Querencio, San Felipe, 16 de noviembre, 1873, Archivo del Dr. Carlos Ma. Querencio (Chávez, 1966: 61).

52 "El Chumbiao", Clarin, 17-7-1968.

${ }^{53}$ Así por ejemplo, en su libro sobre el caudillo entrerriano, afirma que ante la intervención federal a la provincia: "López Jordán no titubea más. Sabe que la autonomía entrerriana va a ser violentamente avasallada por los salvajes y sabe que el pueblo lo respalda con cuerpo y alma. Por eso, sin poder esperar más, el 23 de abril contesta al Liberalismo con un grito de guerra que se expande por los rústicos rancheríos provinciales" y lanza su proclama (Chávez , 1957:220). En Civilización y Barbarie, expresa que los caudillos "patentizan la superioridad de los valores morales frente a la civilización de la levita" en su conducta "resaltan virtudes de solidaridad social, fidelidad al pueblo y una rectitud política incomparable" (Chávez, 1956:16).
} 
Alabart. Gauchos, Montoneras y Caudillos: una Interpretación a través de la historieta el chumbiao, de Fermín...

humanizados: Saá viste ropas de paisano y está escondiéndose de los nacionales; López Jordán en el exilio juega al billar con José Hernández. Son los jefes, ellos planean la rebelión, sus órdenes son acatadas y sus consignas son señales de identificación pero no están lejos de sus seguidores. "El partido se ha descangallado, pero el general Jordán volverá porque es taita..." piensa el Chumbiao.$^{54} \mathrm{El}$ caudillo no va a dejar solos a sus seguidores como un padre no deja solo a sus hijos, de esta manera, Chávez alude a la relación paternalista que los une. Una relación que implica respeto, protección, lealtad y afecto. Cuando López Jordán y el Chumbiao se despiden el texto de la viñeta expresa: "el caudillo federal se alejaba, cavilando sobre sus próximos pasos... y sobre los seres queridos que esperaban allá en su tierra..." mientras el Chumbiao lo observa y piensa: "en una de esas... a lo mejor es la última vez que lo veo al general". ${ }^{55}$

Además del claro liderazgo de López Jordán al que se espera para encabezar el levantamiento y de los jefes federales superiores, en la historieta también aparecen caudillos intermedios que también tienen capacidad personal para movilizar a los gauchos. En una pulpería de Rosario del Tala a la que llega el Chumbiao con sus hombres, se desarrolla el siguiente diálogo:

\author{
"Pulpero: Dice El Comercio q'el general está listo pa la \\ atropellada \\ Paisano 1: ¡Esta güelta me voy con él! \\ Paisano 2: Yo también... me alistaré con el mayor Mendieta". ${ }^{56}$
}

Nos interesa este pasaje por varios motivos, por un lado muestra la circulación de las noticias a través de la lectura en voz alta del periódico y la importancia de las pulperías como espacios de sociabilidad en la campaña, algo que está representado a lo largo de toda la historieta, ${ }^{57}$ por otro, la decisión autónoma de los paisanos para sumarse a la rebelión y la forma de hacerlo, alistándose con un jefe intermedio como el mayor Saturnino Mendieta, un jordanista reconocido del departamento de Rosario del Tala con el que Chumbiao va a entrevistarse para coordinar las operaciones. De esta manera, es posible advertir otra razón que llevaba a los gauchos a unirse a las montoneras: la adhesión a los caudillos, en este caso a López Jordán y también a los caudillos intermedios que lo acompañan. Esta motivación está vinculada con la adhesión política

\footnotetext{
54 "El Chumbiao", Clarin, 7 -3-1967.

55 "El Chumbiao", Clarín, 4-10-1967.

66 "El Chumbiao", Clarín, 23-4-1968.

${ }^{57}$ En las pulperías leen los periódicos, se arman payadas y se cantan poemas, formas de expresión de una cultura oral. Chávez crea un episodio donde el propio Hernández canta algunos versos del Martín Fierro con el que los gauchos se sienten identificados (El Chumbiao, Clarin, 11-10-1967). La transmisión oral del poema en la campaña no se hizo solo a través de la lectura en voz alta sino también por medio del canto, se trata de un fenómeno plenamente documentado en los almacenes y pulperías se reunía el gauchaje a la espera de que alguien leyera el folleto o para escuchar a algún memorioso que hubiera aprendido pasajes enteros, así pronto apareció el recitador cantor profesional que recorría lugares de reunión para declamar el poema acompañándose con su guitarra (Lois, 2003).
} 
partidaria que ya hemos señalado, los gauchos jordanistas de la tira vivan al general López Jordán junto al lema partidario: “"Viva la soberanía de la provincia!". ${ }^{58}$

Por último, en el diálogo al que hicimos referencia, Maragata le aclaraba a Secundino que todos peleaban por lo mismo: "pa que los criollos no siamos carne de cogote". Chávez retoma a Hernández y remite con esa cita casi textual a la situación social que afecta por igual a los pobladores rurales pobres que se hacen matreros: "y si ansí las cosas andan porque quieren los que mandan, aguantemos los azotes". ${ }^{59}$ Los "criollos" comparten una identidad, una situación de "clase" que los une como actores políticos en la lucha contra las injusticias sociales y contra la arbitrariedad de las autoridades, más allá de las fronteras y los caudillos que los representan.

La historieta termina antes de que se produzca la segunda rebelión jordanista de 1873 , en la penúltima viñeta se ve la imagen de López Jordán y de Chumbiao y el siguiente texto: "La imagen de López Jordán lo asaltó, por un momento, con fuerza y sentimiento...Y pensó Barajo, no hay más remedio que seguir peliando...". ${ }^{60}$ Un final abierto para continuar la lucha y las aventuras del montonero jordanista.

Figura 5. Chumbiao y López Jordán. Chávez y Arancio

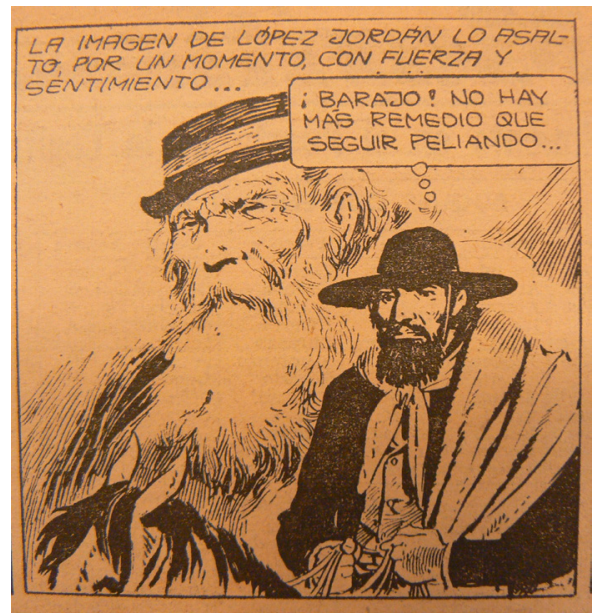

Fuente: "El Chumbiao", Clarín, sábado 30 de agosto de 1969.

\footnotetext{
${ }^{58}$ El lema surge de la proclama que López Jordán dirigió al pueblo entrerriano ante la intervención federal y la llegada del ejército nacional: "Entrerrianos: Os acabo de dar libertad y derecho. Nuestros eternos enemigos no lo quieren reconocer, trayéndonos la guerra, y aquí me tenéis con la lanza en la mano para defenderlos. Si queréís ser libres venid a acompañarme, donde ya dos mil leales entrerrianos me rodean dispuestos a morir antes que dejarse ultrajar. Nuestra guerra no es sino en sostén de la autonomía de Entre Ríos...”. Proclama de López Jordán, 23 de abril de 1870 (Chávez, 1957: 220).

${ }^{59}$ Esta expresión está tomada del canto XII del Martín Fierro de José Hernández en el que Cruz narra sus desventuras y las injusticias hasta hacerse matrero: "Lo miran al pobre gaucho, como carne de cogote: lo tratan al estricote, y si ansí las cosas andan porque quieren los que mandan, aguantemos los azotes" (Hernández, 2008: 76).

60 "El Chumbiao", Clarín, 30 de agosto, 1969.
} 


\section{Algunas conclusiones}

En las Jornadas de Homenaje a Felipe Varela que se realizaron en 1967, Ortega Peña y Duhalde presentaron una ponencia sobre La metodología histórica y el estudio de las luchas civiles del periodo de la organización nacional (Ortega Peña y Duhalde, 1967) en la que, entre otras cuestiones, plantearon una crítica a Fermín Chávez por su excesivo apego a la figura de los caudillos que convertía sus trabajos en biografías eruditas sólo centradas en la vida personal de los mismos, sin la presencia de las masas que eran la fuente de su poder (Stortini, 2004: 93).

Significativamente en ese mismo año Clarín comenzó a publicar la historieta. Sabemos que Chávez tenía evidencias sobre la existencia de Gerónimo Romero desde su investigación sobre López Jordán en la década del ' 50 . Interesado por el personaje y con un conocimiento exhaustivo del período, fue el lenguaje de la historieta el que le permitió trascender los límites que le imponía la disciplina histórica y enfocar su mirada sobre las clases populares, particularmente, los gauchos que integraron la última montonera federal en el contexto de las rebeliones jordanistas. A través del recurso de ficción construyeron una narrativa dibujada junto a Arancio, en la que al mismo tiempo que dotaron al relato de una reconstrucción más viva del pasado, plantearon una representación de los gauchos, su relación con los caudillos y la montonera que complejizó la mirada de los trabajos historiográficos producidos por los revisionistas y que tal como analizamos se emparenta en varios aspectos con estudios recientes sobre la problemática.

En síntesis, para Chávez, los gauchos matreros no eran criminales, ni personas marginales de la campaña, sino trabajadores rurales, peones, desertores, perseguidos políticos, que se transformaron en matreros como un acto político de rebelión contra la autoridad y la montonera fue una de las formas que tomaron las luchas partidarias y una de las maneras en que los gauchos participaron de la política. Las movilizaciones que encabezaron las montoneras no fueron estallidos espontáneos de violencia rural, sino que funcionaban organizadamente, con jerarquías, se definían objetivos y se trazaban planes de acción para conseguirlos. Asimismo, en cuanto a las motivaciones que tenían los gauchos para participar en ellas, hemos señalado que la causa fundamental era la identidad política, aunque se plantean tres dimensiones: la identidad partidaria, la relación con el caudillo fundada en la identificación cultural, personal y partidaria con el líder y la pertenencia de clase.

Así, el lenguaje de la historieta resultó un medio de expresión que le permitió proponer una reconstrucción imaginativa acerca de cómo pudo haber sido la vida de aquellos gauchos matreros y gracias a la mayor libertad para enfocar e ilustrar los sucesos, transmitir una conexión con la experiencia vital de sus protagonistas que, al mismo tiempo que habilitó la comunicación con un público masivo de lectores, ofreció una representación de la historia popular no abordada en los estudios académicos por los historiadores revisionistas.

Por último, hicimos foco en el tratamiento de los gauchos, montoneras y caudillos porque nos interesaba analizar su representación en esa reconstrucción del 
pasado del siglo XIX que propone la historieta, pero "El Chumbiao" también admite una lectura desde su presente.

En la agitada vida política de los años sesenta los revisionistas buscaron en el pasado una fuente de legitimación que diera sentido al compromiso intelectual y a la militancia política. Chávez no estuvo ajeno a esa búsqueda. Gerónimo Romero, alias "El Chumbiao", desertor, bandido, salteador como lo calificaban "los prosélitos de Sarmiento", fue rescatado de las sombras y convertido en el personaje más valiente, leal, recto: un héroe de historieta, y con él, los gauchos y la montonera, se invertía aquella vieja dicotomía donde lo bárbaro había resultado paradójicamente lo propio y lo civilizado, lo ajeno (Chávez, 1974).

\section{Referencias Bibliográficas}

Alabart, M. 2015. "Los desbandes de Basualdo y Toledo: hacia la fractura del federalismo entrerriano" En: Roberto Schmit (comp.), Caudillos, politica e Instituciones en los orígenes de la nación Argentina, Buenos Aires, Ed. Universidad Nacional de General Sarmiento, pp101-131.

Borges, J. L. 2011. "Historias de Jinetes" (1955) Evaristo Carriego. Obras Completas, Tomo 1, Buenos Aires, Editorial Sudamericana.

Buchbinder, P. 1998. "Caudillos y caudillismo: una perspectiva historiográfica". En: Goldman, Noemí y Salvatore, Ricardo, Caudillismos rioplatense. Nuevas miradas a un viejo problema, Buenos Aires, Eudeba, pp. 31-50.

Cataruzza, A. 2011. "El revisionismo itinerario de cuatro décadas". En: Cataruzza A. y Eujanian, A. Politicas de la Historia 1860-1960, Buenos Aires, Alianza.143-182. Contreras, S. 2008. "Intervenciones con Sarmiento: a propósito de "Historias de jinetes'". En: Dabove, P. (Ed.) Jorge Luis Borges: politicas de la literatura. Pittsburgh, Instituto Internacional de Literatura Iberoamericana; 77-99. Disponible en:

http://www.celarg.org/archivos/contreras_borges_iberoamericana.pdf

Cuarterolo, A. 2006. "El retrato fotográfico en la Buenos Aires decimonónica. La burguesía se representa a sí misma". En: Varia Historia, vol. 22, No 35, pp. 39-53. Chávez, F. 1957. Vida y muerte de López Jordán, Buenos Aires, Ediciones Theoría.

Chávez, F. 1966. El revisionismo y las montoneras, Buenos Aires, Ediciones Theoría.

Chávez, F. 1967. Vida del Chacho, Buenos Aires, Ediciones Theoría.

Chávez, F. 1967a. "Cuando la historia visita la leyenda", Clarín Revista, domingo 15 de enero, Buenos Aires.

Chávez, F. 1969. "El Chacho, protector de los gauchos matreros del oeste" en Comisión Central De Homenaje a Ángel Vicente Peñaloza, Buenos Aires: Hachette, pp. 277-299.

Chávez, F. 1974. Civilización y barbarie en la historia de la cultura argentina, Buenos Aires, Ediciones Theoría.

Chávez, Fermín. 1975. "La Argentina es deformada cuando termina el caudillaje" en entrevista realizada por Jorge B. Rivera, Revista Crisis, mayo, Disponible: http:// www.elhistoriador.com.ar/articulos/general/historia_real.php 
De la Fuente, A. 2007. Los hijos de Facundo, Caudillos y Montoneras de la provincia de la Rioja durante el proceso de Formación del Estado Nacional Argentino (1853-1870), Buenos Aires: Prometeo.

Di Meglio, G. y Fradkin, R. Comp. 2013. Hacer política. La participación popular en el siglo XIX rioplatense, Buenos Aires, Prometeo.

Font Ezcurra, R. 1940. "Orígenes de nuestro federalismo". En: Revista del Instituto de Investigaciones Históricas Juan Manuel de Rosas, 6, 68-80.

Fradkin, R. 2006. La historia de una montonera. Bandolerismo y caudillismo en Buenos Aires, 1826, Buenos Aires, Siglo XXI Editores.

Gociol, J. y Rosemberg, D. 2003. La historieta argentina. Una historia, Buenos Aires, Ed. de la Flor.

Goldman, N. y Salvatore, R. (Comp.). 1998. Caudillismo Rioplatenses. Nuevas miradas a un viejo problema, Buenos Aires, Eudeba.

Halperín Donghi, T. 2005. El revisionismo histórico como visión decadentista de la historia nacional, Buenos Aires: Siglo XXI Editores.

Hernández, J. 2008. Martín Fierro, Buenos Aires, Eudeba,

Irazusta, J. 1946. "La crisis de la autoridad en 1920”.En: Revista del Instituto de Investigaciones Históricas Juan Manuel de Rosas, 12, pp.53-80.

Levin, F. 2015. Humor Gráfico. Manual de uso para la historia, Buenos Aires, Ediciones UNGS.

Lynch, J. 1993. Caudillos en Hispanoamérica, 1800-1850, Madrid: Mapfre.

Lois, E. 2003. "Cómo se escribió el Martín Fierro". En: Noé, J. (Dir.), Historia de la literatura argentina. La lucha de los lenguajes, vol. II, Buenos Aires, Emecé Editores, pp.193-224.

Malosetti Costa, L. y Penhos, M. 1991. "Imágenes para el desierto argentino. Apuntes para una iconografía de la pampa", III Jornadas de Teoría e Historia de las Artes Ciudad/campo en las Artes en Argentina y Latinoamérica, Buenos Aires, CAIA, pp.195-204.

Malosetti Costa, L. 2001. Los primeros modernos. Arte y Sociedad en Buenos aires a fines del siglo XIX, Buenos Aires, Fondo de Cultura Económica.

Ortega Peña, R. y Duhalde, E. 1966. Felipe Varela contra el imperio británico, Buenos Aires, Editorial Sudestada.

Ortega Peña, R. y Duhalde, E. 1967. La metodología histórica y el estudio de las luchas civiles del periodo de la organización nacional, Buenos Aires, Sudestada.

Palacio, E. 1939. La historia Falsificada, Buenos Aires, Difusión.

Rivera, J. 1992. Panorama de la historieta en la Argentina. Buenos Aires, Libros del Quirquincho.

Sasturain, J. 1995. El domicilio de la aventura. Buenos Aires, Colihue.

Stortini, J. 2004. "Polémicas y crisis en el revisionismo argentino: el caso del Instituto de Investigaciones Históricas “Juan Manuel de Rosas" (1955-1971)”. En: Devoto, F. y Pagano, N. La historiografia académica y la historiografia militante en Argentina y Uruguay, Buenos Aires, Biblos, pp. 81-106. 